\title{
The Study on the Geo-Morphism Related Characteristics of Shiraz Geomorphic Basin, Fars Province, Iran
}

\author{
Shahide Dehghan ${ }^{1}$, Saeid Eslamian ${ }^{2}$, Amir Gandomkar ${ }^{1}$, Ahmad Khademolhoseiny ${ }^{1}$, \\ Kaveh Ostad-Ali-Askari ${ }^{3 *}$, Vijay P. Singh ${ }^{4}$, Nicolas R. Dalezios ${ }^{5}$, Yohannes Yihdego ${ }^{6}$ \\ ${ }^{I}$ Department of Geography, Najafabad Branch, Islamic Azad University, Najafabad, Iran \\ ${ }^{2}$ Full Professor, Department of Water Engineering, Isfahan University of Technology (IUT), Isfahan, Iran \\ ${ }^{3 *}$ Department of Civil Engineering, Isfahan (Khorasgan) Branch, Islamic Azad University, Isfahan, Iran \\ ${ }^{4}$ Department of Biological and Agricultural Engineering \& Zachry Department of Civil Engineering, Texas A \\ and M University, 321 Scoates Hall, 2117 TAMU, College Station, Texas 77843-2117, U.S.A. \\ ${ }^{5}$ Laboratory of Hydrology, Department of Civil Engineering, University of Thessaly, Volos, Greece \& \\ Department of Natural Resources Development and Agricultural Engineering, Agricultural University of \\ Athens, Athens, Greece. \\ ${ }^{6}$ Snowy Mountains Engineering Corporation (SMEC), Sydney, New South Wales 2060, Australia. Geo- \\ Information Science and Earth Observation (ITC), University of Twente, the Netherlands
}

\begin{abstract}
*Corresponding Author: Dr. Kaveh Ostad-Ali-Askari, Department of Civil Engineering, Isfahan (Khorasgan) Branch, Islamic Azad University, Isfahan, Iran. Emails: Koa.askari@khuisf.ac.ir, Kaveh.oaa2000@gmail.com
\end{abstract}

\begin{abstract}
Generally, hydrologic and geomorphic basins select the basic level of material and energy transmission along geophysical gradient. This is very common and normal. But, if a given basin is not able to direct its basic level of material and energy transmission towards geophysical gradient, it should be taken into account as a very specific case. These kinds of basins are very rare and we can point to Kor and Shiraz geomorphic basins as relevant examples. These two basins share a boundary at eastern part of Shiraz basin. In the current study, geomorphic-related characteristics of Shiraz geomorphic basin are scrutinized. The necessity of analysis of the mentioned issue [1] refers to the point that like other natural basins, Shiraz geomorphic basin is a dynamic one. As a results, it is necessary to have an algorithm ruling geo-climate trend of balanced and sustainable structure of the basin. Study of the geomorphic-related characteristics of Shiraz geomorphic basin has been focused during these thirty years. It is worth noting that climatic changes and fluctuations ruling Shiraz basin are quite separated but they have shared cybernetic composition which states that the resultant of hydro geomorphic structure can represent sustainable and balanced status of that basin. Results should be used to observe behaviors of humans included in Shiraz basin with the help of managers.
\end{abstract}

Keywords: Geo-morphism, Shiraz Geomorphic Basin, Hydrologic

\section{INTRODUCTION}

Different geomorphology-related models have been introduced for climatic changes which cover different geomorphology aspects including water and water flows, corrosion, and movements of earth's crust. Studies in the field of geomorphology are categorized into three groups of historical, catastrophic and systematic [1]. The current study is a systematic one in which Shiraz geomorphological basin is investigated. According to the fact that systematic point of view is of great complexity, Shiraz geomorphic basin is shaped in the form of Jurassian screw, especially in the form of a syncline. The mentioned basin is the same as the Zagros mountains from the structural and morph-tectonic as well as morph climatic point of view. Basic level of Maharloobasinis located in a Zagros folded syncline valley. Screwed structure of the mentioned basin is made up of three geomorphological units and tectonic cavity which has been under the effect of tectonic, climatologic and hydro geomorphic logical processes [2]. According to the fact that Zagros grand basin select free level of Persian Gulf as its basic level, Shiraz geomorphological basin is considered a dynamic one. Consequently, it is necessary to have an algorithm ruling geo-climate trend of balanced and sustainable structure of the basin. Actually, it is stated that future prediction based on evidence and 
The Study on the Geo-Morphism Related Characteristics of Shiraz Geomorphic Basin, Fars Province, Iran

documents can be a valid index of the past changes. Application of this method for future study of Shiraz geo-climate system as well as identification of the effects of the factors which affect climatic system of Shiraz basin is of the vital importance. The mentioned necessity can be an invaluable tool to study such complicated issues as changes of Shiraz geomorphic basin in which the study is based on conception and comprehension. As a result, Shiraz geo-climate measures have been scrutinized. These measures are useful tools to find out the effects of various options while reliance on these measure requires a great care. Additionally, their limitations have to be taken into account [3-18].

\section{Methods AND MATERials}

Shiraz geomorphic basin with the area of 393184 square kilometers and perimeter of 38203 kilometer includes Gooyom, Sadra, Golestan, Shiraz and Maharloo as well as Sarvestan. According to metric georeferenced system and geographical coordination of Zone 39, clear overlap is seen while Shiraz geomorphic basin and city of Shiraz do not completely overlap. According to the central role of city of Shiraz in the given geomorphic basin, it is possible to name the basin "Shiraz basin" while it is also possible to name the basin "Maharloo" due to basic-level of the basin. Due to the overlap of Maharloo and Sarvestan at east-south boundary, the basin can be called "Saravestanbasin" as well. However, it is more reasonable to name the basin as "Shiraz basin" due to the vital role of city of shiraz. To have physiographic interpretations of the given basin, it is required to refer to topographic maps with the scale of 25000, 50000, 250000 and 500000. Satellite database and ground or aerial mapping are of great use as well.

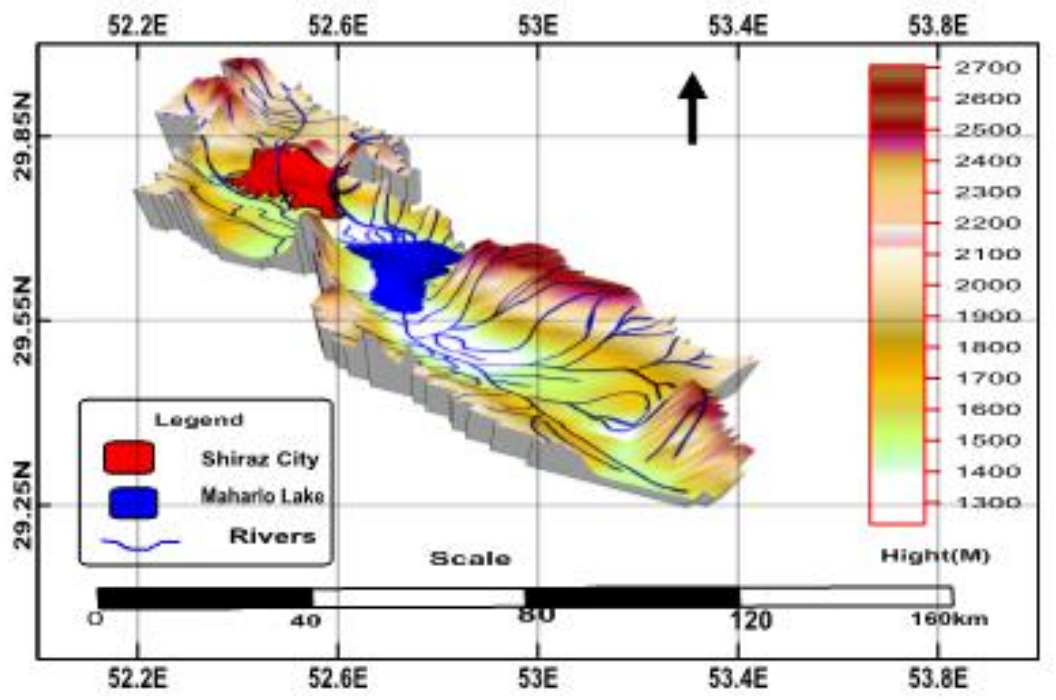

Figure1. 3D map view of the geomorphic basin of Shiraz

The next step is aimed at transmitting digital data extracted out of 7 resources into geographical information system to have a detailed view of the mentioned basin. Figure 1 shows the schematic view of Shiraz geomorphic basin, an independent hydrologic basin, which has more than $95 \%$ overlap with geomorphic basin. The plateau on which city of shiraz is located is shown in red on the map. Actually, it is located above Maharloobasic-level. It is worth noting that ordinary people deem basiclevel of Maharloo as lake which is in fact of Karst type based on geomorphological, hydrologic and geo-climate characteristics of Maharloobasin. It plays an important role in geohydrology of geomorphic zones and neighboring zones as well. The last one is actually evident according to geoneurotic status of hydrographic network of Maharloo.

\subsection{Geo-Morphism Related Characteristics of Shiraz Basin}

Shiraz geomorphic basin is unique in terms of structure and form. The value of collecting information about this structure is related to its interaction with geomorphic characteristics and climatic factors. However, geomorphic characteristics of the mentioned basin are analyzed implicitly. Outputs of calculating height of Shiraz geomorphic basin are emerged in different forms including [19-48]:

1. Gooyom

2. Plateau of Shiraz 
The Study on the Geo-Morphism Related Characteristics of Shiraz Geomorphic Basin, Fars Province, Iran

3. Maharloo lake which can be taken as basic-level

4. Sarvestan fault

5. Darian fault

6. Shiraz fault

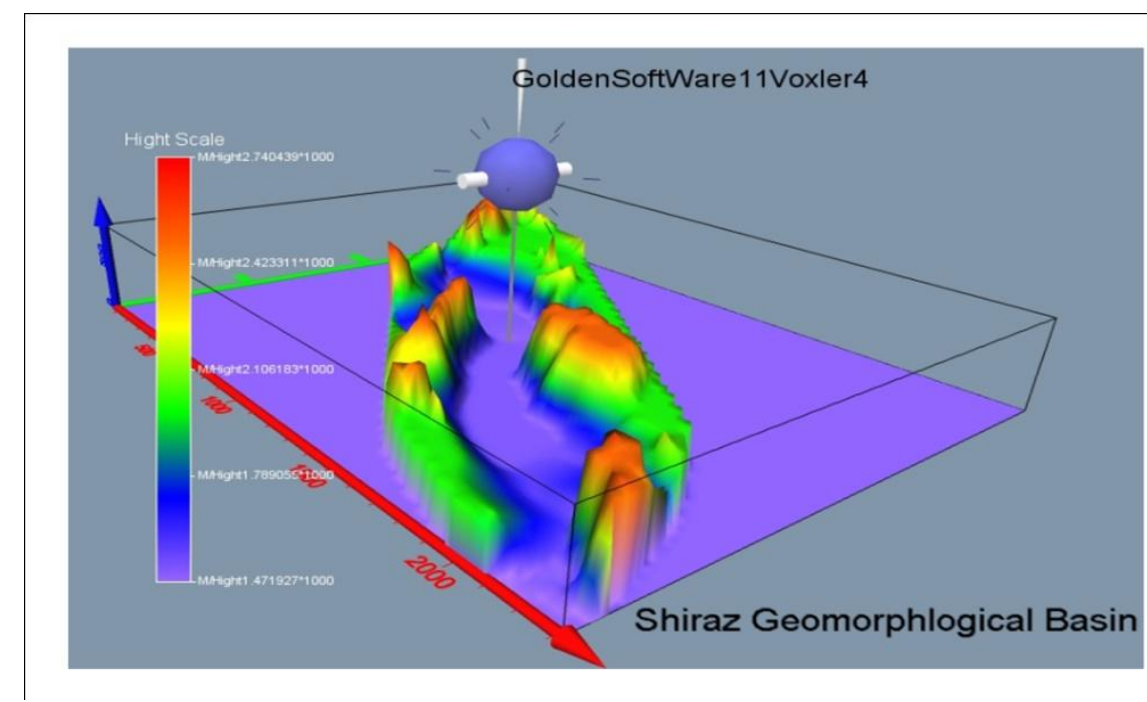

Figure2. Represents Voxels output three-dimensional analog of height of Shiraz geo-morphism basin using filter of 0.2-0.85

Shiraz plateau which is located on top of the plane represents formic status of Shiraz plateau. The mentioned plateau is located in Shiraz geomorphological basin which can be seen on top of the picture in small scale.

\subsection{Geo-Morphism-Related Characteristics of Gooyom Graben}

Faults are categorized into different groups in terms of direction of their movements. As for superficial faults, two concepts of gradient and elongation are presented. It is possible to calculate these two concepts as well. Based on one categorization, faults are categorized into two groups: slip faults and trans current faults.

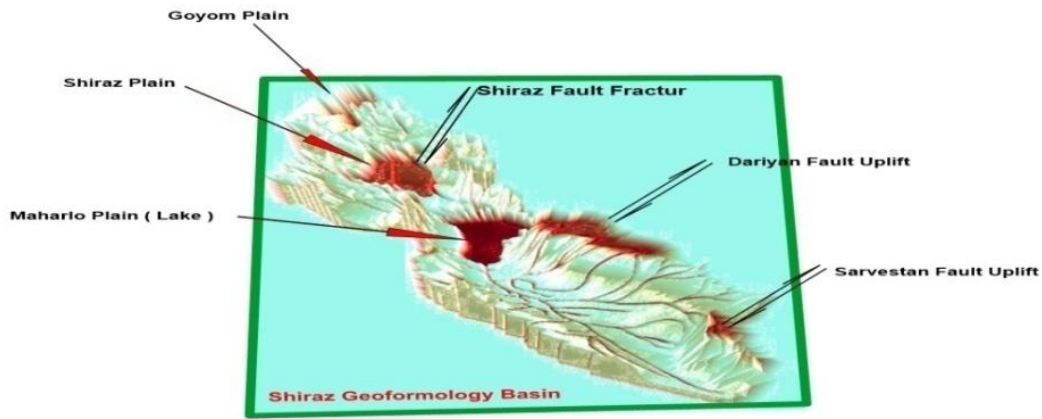

Figure3. Shows a voxels output analog of height of Shiraz geomorphological basin using filter 0.7-0.85.

As for slip faults, the degree of movement along gradient of the given fault is calculated while in trans current faults, horizontal movement parallel to the given fault is calculated. Slip faults are those faults in which movement or slip is occurred along gradient of the fault. Keep in mind that it is not possible to figure out if the what part of the fault underwent movement just by looking at the fault. The only thing to guess is the direction of that movement. As for the surfaces of slip fault, the block positioned above the fault is called hanging wall while the block positioned under the fault is called foot wall. Due to tension, some faults are created which in combination with the neighboring faults lead to 
The Study on the Geo-Morphism Related Characteristics of Shiraz Geomorphic Basin, Fars Province, Iran

normal faults. These faults are a series of faults with different gradients in terms of direction. In these cases, blocks under the fault are called Graben and blocks above the fault are called horst. Gooyom plateau is a good example (figures and). However, area of the mentioned plateau is of classic status [49-84].

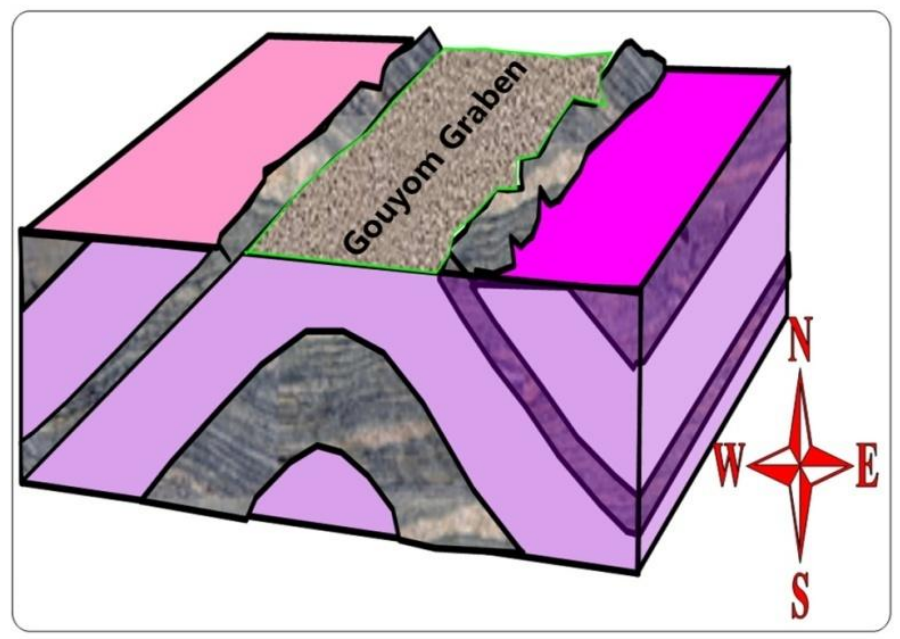

Figure4. Represents tectonic model of Gooyom Graben for Shiraz geomorphological basin

\subsection{Geo-Morphism Related Characteristics of Shiraz Graben}

Results of spatial analysis provide three-dimensional inputs for topography of Shiraz geomorphic Graben which is seen in figure 5. The figure shows that the mentioned Graben is cut by faults so that it can be seen on the picture. More specifically, one fault in the middle of that plateau is under the effect of that occurrence. This condition affects geo-neurotic features of the basin severely. Additionally, it is under the influence of hydrographic network. Geo-neurotic network is also under the effect of changes and fluctuations of the climatic system of the given basin.

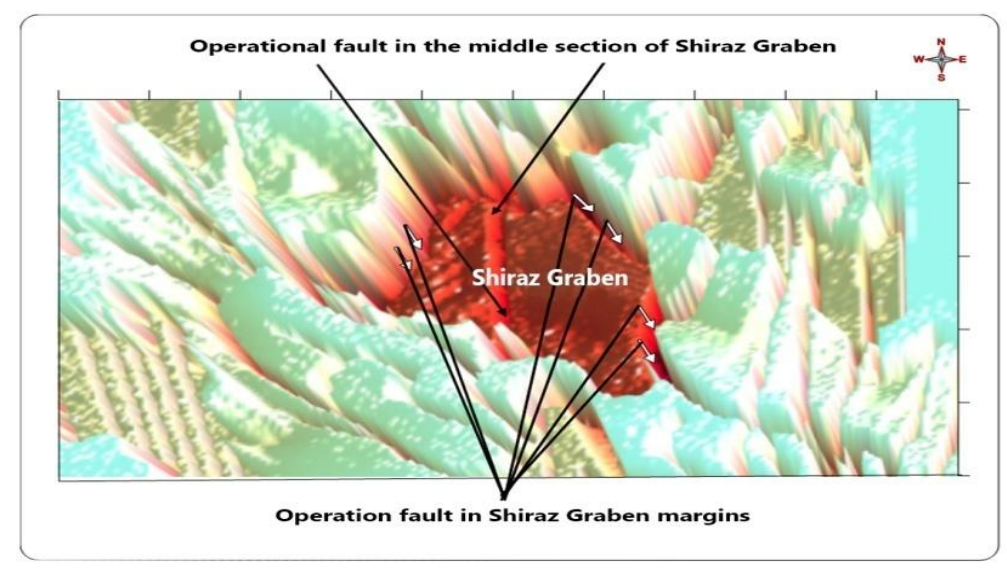

Figure5. Represents voxel analog for Shiraz geo-tectonic plateau considering the spectrum of .45-.95

\subsection{Geo-Morphism Related Characteristics of Maharloo Geological Basic Level}

Maharloo lake is considered the basic level of Shiraz geomorphological basin. This lake which was created due to 89synclinal fault subsidence are supplied by Nahr-e-Azam, Chenar-e-Rahdar, and Nazarabad rivers. Accordingly, chinar-e-rahdar river originates from Adam mountains and passes southern Chenardast and finally reaches Maharloo. Nazarabad river originates from Nazarabad and Selow mountains located at east-south section of Maharloolagoon and passes Sarvestan plateau to reach Maharloo lagoon. However, the area of this lake differs in different seasons. Actually, the dependence is on annual precipitation, vaporization, lime alluvia of Sachoon formation, salt domes located at east section of the lake, water of Maharloo lake which is laden with Sodium chloride, magnesium, sodium sulfate. It is one of the most important salt resources so that its salt is used for 
The Study on the Geo-Morphism Related Characteristics of Shiraz Geomorphic Basin, Fars Province, Iran

petroleum industry. Maharloo lake which is of 1450 meters' height in the lowest section to 1500 meters along the boundaries can be deemed as basic level of Shiraz geomorphological basin. According to geographical information system, it seems to be true that Maharloo is a kind of geographical cavities created due to an echelon folds. Geomorphological difference between these two Grabens can be clearly seen in figure 5. On the other hand, it is stated that Shiraz plateau has been under the influence of geotectonic while Maharloo basic level is a geological cavity created due to an echelon folds. Although east and west sections of Mharloo cavity is severely under the influence of tectonics, status of Maharloo plateau as a Jraben is completely determined. Additionally, an uplift fault is seen around Sarvestan which is unique in terms of hydrographical features. The fact that Daiyan fault is also an uplift one can be of vital significance. It is claimed that Shiraz plateau is unsustainable, especially due to the fault line passing the middle section of the given plateau [85-102].

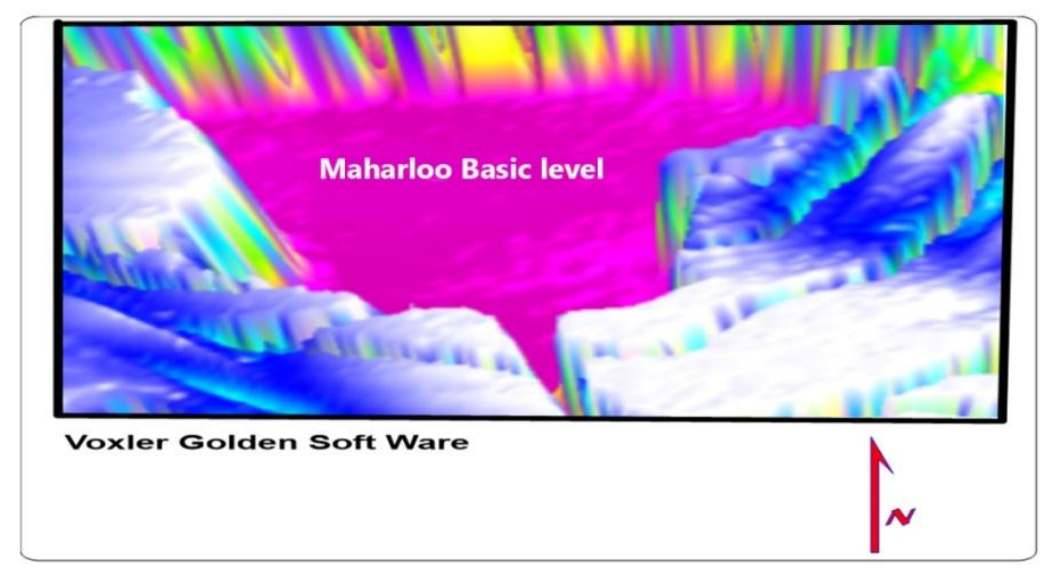

Figure6. Another Fault Located in Shiraz Basin (figure 7) is Dariyan Fault

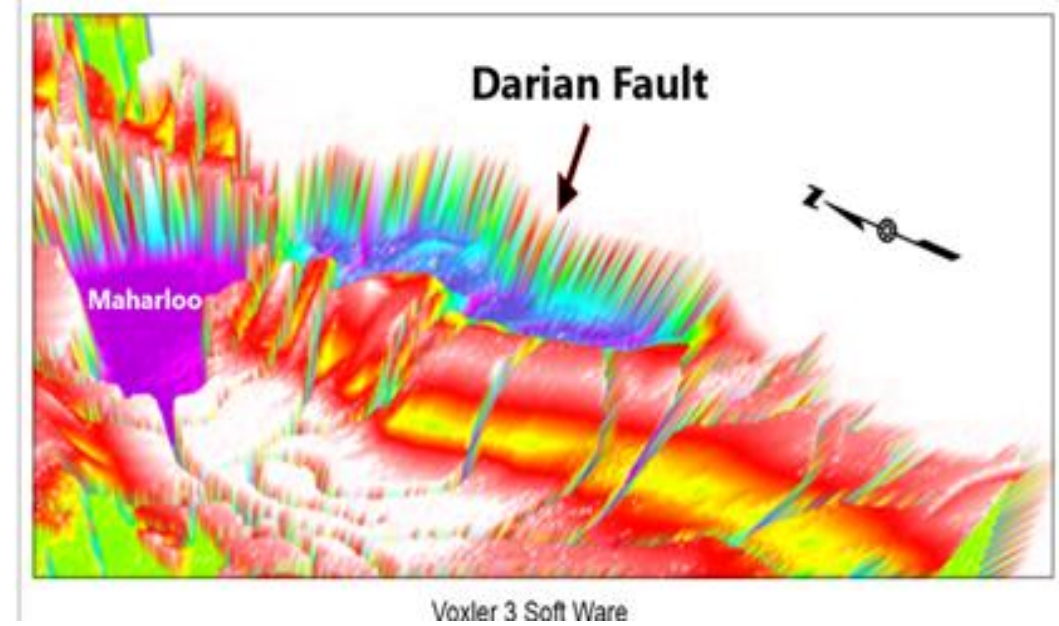

Figure7. Daryan fault and its role in hydrological alignment of hydrographic network of Shiraz geomorphic basin in the range of 0.2 to $0.9 \mu \mathrm{m}$

\subsection{Zoning of Shiraz Geo-Morphism Basin}

In geomorphological point of view, Shiraz basin is categorized into multiple zones:

1. Anticlines which cover east and west basins in discrete way. As a matter of fact, it is the main reason for independence of that basin so that the basin is of 2000 meters' height. The reason for discreteness of anticlines can be the role of tectonic movements.

2. Synclines: there is a continuous syncline which elongates from west-north to east-south. It is located in between anticlines. The mentioned syncline is actually a cavity north of which is of tectonic nature and center of which is of structural nature and south of which is also is a combination of tectonic and echelon fold. As a matter of fact, the cavity is laden with alluvia and this may be the reason for the formation of Shiraz plateau. In the middle section, the given cavity is laden with water and accordingly, it is the very place for Maharloo basic level. (figure 9) 
The Study on the Geo-Morphism Related Characteristics of Shiraz Geomorphic Basin, Fars Province, Iran

3. Faults whose role is in geomorphic gradient of the basin. Even it may lead to emergence of unique structures, especially parallel to the movement of geo-neurotic network of the basin.

4. Hydrographical network which is reaching Mahraloo basic level.

Accordingly, the composition of Shiraz geomorphic basin can be a heavy but dynamic system. Shiraz geomorphological basin is under the influence of four tectonic fault cuts.

1. Gouyom fault which leads to the formation of Gouyom Graben

2. Shiraz subsidence which is the bed for Shiraz city

3. Uplift of right margin of Mahrloo in the distance between Darian and Mahrloo

4. Uplift of Sarvestan in the distance between Fasa and Shiraz geomorphological basin

Satellite pictures have shown that some changes have happened to the gradient of this zone which are beyond Shiraz geomorphological basin. On the other hand, triplet zones are seen on the geotectonic surface which are the result of quaternary climatic changes. According to figure 8, neo-tectonics may lead to over thrust faults and then, quaternary changes and fluctuations have their influence upon the basin. Consequently, Shiraz geomorphological basin is under the influence of changes and fluctuations. These changes and fluctuations is of tectonic nature. According to the geological structure of the basin, tectonic changes are seemed far-fetched. But, the main point is that the effects of climatic processes are inevitable. Accordingly, during the study of this basin, it is not reasonable to rely only on internal factors. On the other hand, geomorphic and climatic factors are also in cybernetic balance [103-143].

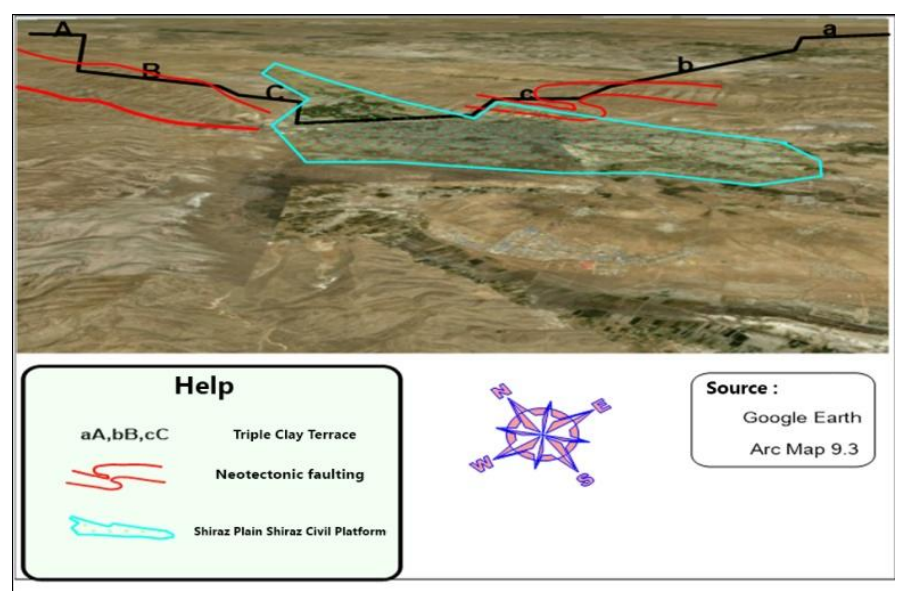

Figure8. Geotectonic and Chlamytic Landforms of the Geomorphic Basin of Shiraz

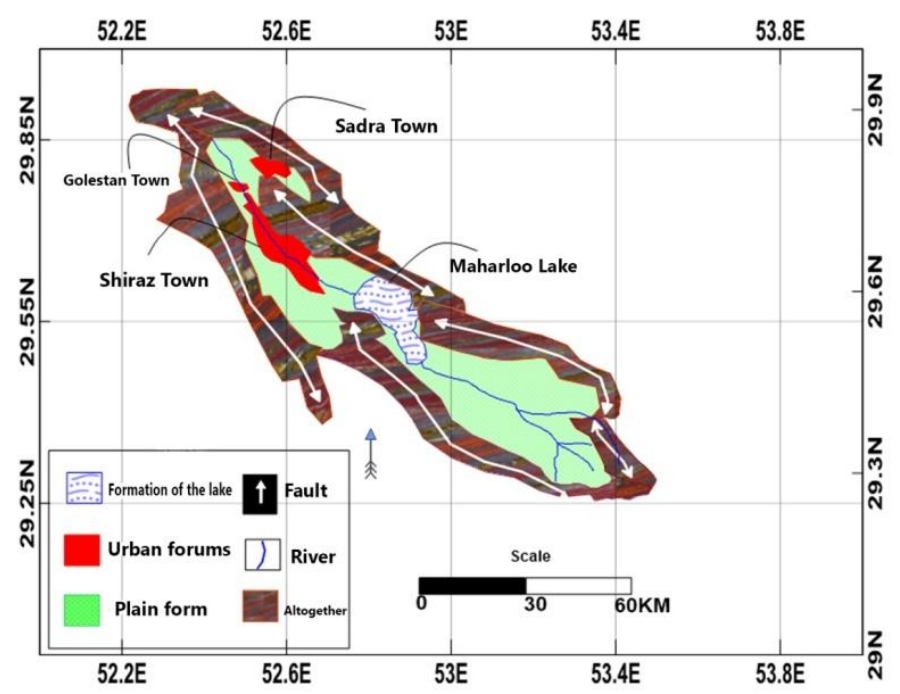

Figure9. Geomorphic zonation of Shiraz Basin 
The Study on the Geo-Morphism Related Characteristics of Shiraz Geomorphic Basin, Fars Province, Iran

\section{RESULTS AND DISCUSSION}

Similar to other basins, Shiraz geomorphological basin is of dynamic nature. Accordingly, it is necessary to have an algorithm ruling geo-climate trend of balanced and sustainable structure of the basin. Actually, it is stated that future prediction based on evidence and documents can be a valid index of the past changes. Application of this method for future study of Shiraz geo-climate system as well as identification of the effects of the factors which affect climatic system of Shiraz basin is of the vital importance. The mentioned necessity can be an invaluable tool to study such complicated issues as changes of Shiraz geomorphic basin in which the study is based on conception and comprehension. As a result, Shiraz geo-climate measures have been scrutinized. These measures are useful tools to find out the effects of various options while reliance on these measure requires a great care. Additionally, their limitations have to be taken into account. The best basin management system is management of crisis. The reason why this option has been chosen is related to the fact that in crisis management system, proportionate proceedings are taken into account for each demand. Additionally, if an unexpected change or fluctuation pops up during the administration of the management system, some costs are incurred because the basin moves back to its previous balanced and sustainable status. It is claimed that crisis incurs some costs. As for planning and risk management systems, changes or fluctuations are predicted so some capital is saved for the time of crisis. These costs are not required and are not possible to be collected in the given basin.

\section{REFERENCES}

[1] Hafeznia, Mohammad Reza. 2009. A introduction to research methodology in humanities. Samt publication. Vol. 321.

[2] Zomorodian, Jafar. 2012. Study of hydrological landforms of Mahrloo basin based on the mutual interaction of morphological, morphs-climatic and hydro-morphological processes. Journal of geography and regional development. Vol. 19. Summer and fall.

[3] Gargouri-Ellouze, E. and Eslamian, S. 2014, Application of Copulas in Hydrology: Geomorphological Instantaneous Unit Hydrograph and Intensity Index of Infiltration Frequency, in Handbook of Engineering Hydrology, Ch. 1, Vol. 2: Modeling, Climate Changes and Variability, Ed. By Eslamian, S., Francis and Taylor, CRC Group, USA, 1-18.

[4] Garg, V. and Eslamian, S., 2017, Monitoring, Assessment, and Forecasting of Drought Using Remote Sensing and the Geographical Information System. Ch. 14 in Handbook of Drought and Water Scarcity, Vol. 1: Principles of Drought and Water Scarcity, Ed. by Eslamian S. and Eslamian F., Francis and Taylor, CRC Press, USA, 217-252.

[5] Kambona, O. O., Stadel, C. and S. S. Eslamian, 2011, Perceptions of tourists on trial use and management implications for Kakamega Forest, Western Kenya, Journal of Geography and Regional Planning Vol. 4, No. 4, 243-250.

[6] Eslamian, S. S. and S. A. Gohari, 2006, Investigation of Flooding Process in South-Esfahan Basin, International Congress of Islamic World Geographers, Esfahan University, Isfahan.

[7] Eslamian, S. S., Nasri, M. and N. Rahimi, 2009, Investigating the drought and wet period and its impact on water resources changes in Bouein plain watershed, Geography and Environment Planning, Vol. 20, No. 33, 75-90.

[8] Yousefi, N., Khodashenas, S. R., Eslamian, S. and Askari, Z. 2016. Estimating width of the stable channels using multivariable mathematical models, Arab. J. Geosci., Vol. 9, No. 321, DOI 10.1007/s 12517-016-2322-0.

[9] Kamali, M. I., Nazari, R., Fridhosseini, A., Ansari, H., Eslamian, S., 2015, The Determination of Reference Evapotranspiration for Spatial Distribution Mapping Using Geostatistics, Vol. 29: 3929-3940.

[10] Kamali, M. I., Nazari, R., Faridhosseini, A., Ansari, H., Eslamian, S., 2015, The Determination of Reference Evapotranspiration for Spatial Distribution Mapping Using Geo-statistics, Water Resources Management, 29:3929-3940

[11] Saatsaz, M., Azmin-Sulaiman, W. N., Eslamian, S., Mohammadi, K., 2013, Hydrogeochemistry and groundwater quality assessment of Astaneh-Kouchesfahan Plain, Northern Iran, International Journal of Water, Vol. 7, No. 1/2, $44-65$.

[12] Kambona, O. O., Stadel, C. and S. S. Eslamian, 2011, Perceptions of tourists on trial use and management implications for Kakamega Forest, Western Kenya, Journal of Geography and Regional Planning Vol. 4, No. 4, 243-250. 
The Study on the Geo-Morphism Related Characteristics of Shiraz Geomorphic Basin, Fars Province, Iran

[13] Kohansal, M. M., Mohamadi, O., Eslamian, S. S. and M. Kohansal, 2014, Inter-basin Transfer and Saving Uremia Lake by Sustainable Development Approach, The 32nd National and the 1st International Geosciences Congress, Uremia, Iran.

[14] Bazrkar, M.H., Zeyaei, R., and Eslamian, S.S., 2013, Eutriphication: a Water Body's Problem, International Symposium on Ecohydrology, Biotechnology and Engineering: Towards the Harmony Between Biogeosphere and Society on the Basis of Long Term Ecosystem Research, September 16-22, Lodz, Poland.

[15] Abedi-Koupai, J., Eslamian, S. S. and Fakouri, F., 2010, The Effects of Applying Treated Wastewater on the Physical and Mechanical Behavior of Soil-Root Interactions, Geophysical Research Abstracts, Vol. 12, EGU2010-13610, EGU General Assembly, Vienna, Austria.

[16] Eslamian, S. S. and S. A. Gohari, 2006, Investigation of Flooding Process in South-Esfahan Basin, International Congress of Islamic World Geographers, Esfahan University, Isfahan.

[17] Eslamian S. S., 2004, Evaporation Modeling for Some Dam Reservoirs in Iran, Western Pacific Geophysics Meeting, Hawaii Convention Center, Honolula, Hawaii.

[18] Gazavi, R. and S. Eslamian, 2006, Runoff in an Iranian Karstic Watershed as Compared with a Neighbor Non-Karstic Watershed, 8th Conference on Limestone Hydrogeology, Neuchâtel, Switzerland.

[19] Eslamian, S. S., Nasri, M. and N. Rahimi, 2009, Investigating the drought and wet period and its impact on water resources changes in Bouein plain watershed, Geography and Environment Planning, Vol. 20, No. 33, 75-90.

[20] Eslamian, S., 2014, (ed.) Handbook of Engineering Hydrology, Vol. 2: Modeling, Climate Change and Variability, Taylor and Francis, CRC Group, USA, 646 Pages.

[21] Dalezios, N. R., Gobin, A., Tarquis Alfonso, A. M., and Eslamian, S., 2017, Agricultural Drought Indices: Combining Crop, Climate, and Soil Factors, Ch. 5 in Handbook of Drought and Water Scarcity, Vol. 1: Principles of Drought and Water Scarcity, Ed. by Eslamian S. and Eslamian F., Francis and Taylor, CRC Press, USA, 73-90.

[22] Nazif, S. and Tavakolifar, H., Eslamian, S., 2017, Climate Change Impact on Urban Water Deficit, Ch. 5 in Handbook of Drought and Water Scarcity, Vol. 2: Environmental Impacts and Analysis of Drought and Water Scarcity, Ed. by Eslamian S. and Eslamian F., Francis and Taylor, CRC Press, USA, 81-106.

[23] Shahid, S., Alamgir, M., Wang, X.-J., Eslamian, S., 2017, Climate Change Impacts on and Adaptation to Groundwater, Ch. 6 in Handbook of Drought and Water Scarcity, Vol. 2: Environmental Impacts and Analysis of Drought and Water Scarcity, Ed. by Eslamian S. and Eslamian F., Francis and Taylor, CRC Press, USA, 107-124.

[24] Maleksaeidi, H., Keshavarz, M., Karami, E., Eslamian, S., 2017, Climate Change and Drought: Building Resilience for an Unpredictable Future, Ch. 9 in Handbook of Drought and Water Scarcity, Vol. 2: Environmental Impacts and Analysis of Drought and Water Scarcity, Ed. by Eslamian S. and Eslamian F., Francis and Taylor, CRC Press, USA, 163-186.

[25] Zareeian, M.J., Eslamian, S., Gohari, A., and Adamowski, J. 2017. The Effect of Climate Change on Watershed Water Balance, in Mathematical Advances Towards Sustainable Environmental Systems, Ed. by Furze, J.N., Swing, K., Gupta, A.K., McClatchey, R., Reynolds, D., Springer International Publishing, Switzerland, 215-238.

[26] Bazrkar, M. H., Zamani, N., Eslamian, S., Eslamian, A., Dehghan, Z., 2015, Urbanization and Climate Change, Handbook of Climate Change Adaptation, Ed. By Leal Filho, W., Springer, 619-655.

[27] Gohari, A., Zareeian, M. J. and Eslamian, S., 2015, A multi-model framework for climate change impact assessment, Handbook of Climate Change Adaptation, Ed. By Leal Filho, W., Springer, 17-35.

[28] Noor Islam, Sh., Reinstädtler, S., and Eslamian, S., 2015, Water Reuse Sustainability in Cold Climate Regions, Urban Water Reuse Handbook, Ch. 68, Ed. By Eslamian, S., Taylor and Francis, CRC Group, 875-886.

[29] Salequzzaman, MD., Tariqul Islam, S. M., Shiddi quzzaman, M., and Eslamian, S., 2015. Climate Change Adaptation and Water Reuse, Urban Water Reuse Handbook, Ch. 75, Ed. By Eslamian, S., Taylor and Francis, CRC Group, 969-980.

[30] Kumar Goyal, M., Singh, V., and Eslamian, S., 2015, Impact of Climate Change on Drinking Water, Urban Water Reuse Handbook, Ch. 76, Ed. By Eslamian, S., Taylor and Francis, CRC Group, 981-1006.

[31] Gargouri-Ellouze, E. and Eslamian, S. 2014, Application of Copulas in Hydrology: Geomorphological Instantaneous Unit Hydrograph and Intensity Index of Infiltration Frequency, in Handbook of Engineering Hydrology, Ch. 1, Vol. 2: Modeling, Climate Changes and Variability, Ed. By Eslamian, S., Francis and Taylor, CRC Group, USA, 1-18. 
[32] Mujere, N. and Eslamian, S. 2014, Climate Change Impacts on Hydrology and Water Resources, in Handbook of Engineering Hydrology, Ch. 7, Vol. 2: Modeling, Climate Changes and Variability, Ed. By Eslamian, S., Francis and Taylor, CRC Group, USA, 113-126.

[33] Farzaneh, M. R., Eslamian, S. and Mirnezami, S. J. E. 2014, Climate Change: Uncertainty, Impact, and Adaptation, in Handbook of Engineering Hydrology, Ch. 8, Vol. 2: Modeling, Climate Changes and Variability, Ed. By Eslamian, S., Francis and Taylor, CRC Group, USA, 127-146.

[34] Goodarzi, E. and Eslamian, S. 2014, Dam Risk and Uncertainty, in Handbook of Engineering Hydrology, Ch. 9, Vol. 2: Modeling, Climate Changes and Variability, Ed. By Eslamian, S., Francis and Taylor, CRC Group, USA, 147-171.

[35] Fakhri, M., Dokohaki, H., Eslamian, S., Fazeli Farsani, I. and Farzaneh, M. R. 2014, Flow and Sediment Transport Modeling in Rivers, in Handbook of Engineering Hydrology, Ch. 13, Vol. 2: Modeling, Climate

[36] Changes and Variability, Ed. By Eslamian, S., Francis and Taylor, CRC Group, USA, 233-275.

[37] Matouq, M., Al-Bilbisi, H., El-Hasan, T. and Eslamian, S. 2014, GIS Applications in a Changing Climate, in Handbook of Engineering Hydrology, Ch. 15, Vol. 2: Modeling, Climate Changes and Variability, Ed. By Eslamian, S., Francis and Taylor, CRC Group, USA, 297-312.

[38] Noor Islam, S., Gnauck, A., Voigt, H.-J. and Eslamian, S., 2014, Hydrological Changes in Mangrove Ecosystems, in Handbook of Engineering Hydrology, Ch. 18, Vol. 2: Modeling, Climate Changes and Variability, Ed. By Eslamian, S., Francis and Taylor, CRC Group, USA, 353-373.

[39] Kałuża, T. and Eslamian, S. 2014, Impact of the Development of Vegetation on Flow Conditions and Flood Hazards, in Handbook of Engineering Hydrology, Ch. 21, Vol. 2: Modeling, Climate Changes and Variability, Ed. By Eslamian, S., Francis and Taylor, CRC Group, USA, 415-449.

[40] Rahman, A., Haddad, Kh. and Eslamian, S., 2014, Regional Flood Frequency Analysis, 2014, in Handbook of Engineering Hydrology, Ch. 22, Vol. 2: Modeling, Climate Changes and Variability, Ed. By Eslamian, S., Francis and Taylor, CRC Group, USA, 451-469.

[41] Vafakhah, M. and Eslamian, S. 2014, Regionalization of Hydrological Variables, in Handbook of Engineering Hydrology, Ch. 23, Vol. 2: Modeling, Climate Changes and Variability, Ed. By Eslamian, S., Francis and Taylor, CRC Group, USA, 471-499.

[42] Chowdhury, R. K. and Eslamian, S. 2014, Statistical Parameters Used for Assessing Hydrological Regime, in Handbook of Engineering Hydrology, Ch. 26, Vol. 2: Modeling, Climate Changes and Variability, Ed. By Eslamian, S., Francis and Taylor, CRC Group, USA, 537-551.

[43] Mujere, N. and Eslamian, S. 2014, Impact of Urbanization on Runoff Regime, Chowdhury, R. K. and Eslamian, S. 2014, Statistical Parameters Used for Assessing Hydrological Regime, in Handbook of Engineering Hydrology, Ch. 29, Vol. 2: Modeling, Climate Changes and Variability, Ed. By Eslamian, S., Francis and Taylor, CRC Group, USA, 605-615.

[44] Fakhri, M., Farzaneh, M. R., Eslamian S. and Nazari, R., 2013, Wind speed regionalization under climate change conditions, Chapter 10, New Developments in Renewable Energy by H. Arman \& I. Yukcel, 215236.

[45] Eslamian, S. S., Gilroy K. L. and R. H. McCuen, 2011, Climate Change Detection and Modeling in Hydrology, Ch. 5 in "Climate Change -Research and Technology for Adaptation and Mitigation" Edited by J. Blanco and H. Kheradmand, InTech, 87-100.

[46] Kouhestani, S., Eslamian, S.S., Abedi-Koupai, J. and Besalatpour, A.A., 2016. Projection of climate change impacts on precipitation using soft-computing techniques: A case study in Zayandeh-rud Basin, Iran. Global and Planetary Change, No. 144, 158-170.

[47] Zareian, M. J. and Eslamian, S., 2016, Variation of water resources indices in a changing climate, International Journal of Hydrology Science and Technology, Vol. 6, No. 2, 173 - 187.

[48] Fathian, F., Dehghan, Z.., Eslamian, S., Adamowski, J., 2016, Assessing Irrigation Network Performance Based on Different Climate Change and Water Supply Scenarios: A Case Study in Northern Iran, International Journal of Water, Accepted.

[49] Fathian, F., Dehghan, Z.., Eslamian, S., 2016, Evaluating the impact of changes in land cover and climate variability on streamflow trends (case study: eastern subbasins of Lake Urmia, Iran), J. Hydrology Science and Technology, Vol. 6, No. 1, 1-26.

[50] Zareian, M. J., Eslamian, S. and Safavi, H. R., 2015, A modified regionalization weighting approach for climate change impact assessment at watershed scale, Theor. Appl. Climatol., 122:497-516.

[51] Matouq, M., El-Hasan, T., Al-Bilbisi, H., Abdelhadi, M., Hindiyeh, M., Eslamian, S. and S. Duheisat, 2013, The climate change implication on Jordan: A case study using GIS and Artificial Neural Networks for weather forecasting, Journal of Taibah University for Science, Vol. 7, No. 2, 44-55. 
The Study on the Geo-Morphism Related Characteristics of Shiraz Geomorphic Basin, Fars Province, Iran

[52] Fakhry, M., Farzaneh, M. R., Eslamian, S. S. and M. J. Khordadi, 2013, Confidence interval assessment to estimate dry and wet spells under climate change in Shahrekord Station, Iran, ASCE, Journal of Hydrologic Engineering, Vol. 18, No. 7, 911-918.

[53] Zamani Nuri, A., Farzaneh, M. R., Fakhri, M., Dokoohaki, H., Eslamian, S. and Khordadi, M. J., 2013, Assessment of future climate classification on Urmia Lake basin under effect of climate change, Int. J. Hydrology Science and Technology, Vol. 3, No. 2, 128-140.

[54] Gohari, A., Eslamian, S., Abedi-Koupaei, J., Massah-Bavani, A., Wang, D., Madani, K., 2013, Climate change impacts on crop production in Iran's Zayandeh-Rud River Basin. Science of The Total Environment, Vol. 442, 405-419.

[55] Abdolhosseini, M., Eslamian, S., Mousavi, S. F., 2012, Effect of climate change on potential evapotranspiration: a case study on Gharehsoo sub-basin, Iran, Vol. 2 No. 4, 362-372.

[56] Farzaneh, M. R., Eslamian, S. S., Samadi, Z. and A. Akbarpour, 2012, An appropriate general circulation model (GCM) to investigate climate change impact, International Journal of Hydrology Science and Technology, Vol. 2, No. 1, 34-47.

[57] Fakhri, M., Farzaneh, M. R., Eslamian, S. and M. J. Khordadi, 2012, Uncertainty Assessment of Downscaled Rainfall: Impact of Climate Change on the Probability of Flood, Journal of Flood Engineering, Vol. 3, No. 1, 19-28.

[58] Farzaneh, M. R., Eslamian, S. S., Samadi, Z. and A. Akbarpour, 2012, An appropriate general circulation model (GCM) to investigate climate change impact, International Journal of Hydrology Science and Technology, Vol. 2, No. 1, 34-47.

[59] Amiri, M. J. and S. S. Eslamian, 2010, Investigation of climate change in Iran, Journal of Environmental Science and Technology, Vol. 3, No. 4, 208-216.

[60] Eslamian, S. S. and H. Hasanzadeh, 2009, Detecting and Evaluating Climate Change Effect on Frequency Analysis of Wind Speed in Iran, International Journal of Global Energy Issues, Special Issue on Wind Modelling and Frequency Analysis (WMFA). Vol. 32, No. 3, 295 - 304.

[61] Modarres, R., Soltani, S. and S. S. Eslamian, 2007, The Use of Time Series Modeling for the Determination of Rainfall Climates of Iran, International Journal of Climatology, Vol. 27, No. 6, 819829.

[62] Zareian, M .J., Eslamian, S.S., Safavi, H. R., Eslamian, 2015, A. Effect of Climate Change on Reference Evapotranspiration Based on Weighting Methods, 4th Climate Change Technology Conference, May 2527, Montreal, Canada.

[63] Zareian, M.J., Eslamian, S.S., Gohari, A. and Hosseinipour, E.Z., 2014, Climate Change Impacts on Reservoir Inflow Using Various Weighting Approaches, World Environmental and Water Resources Congress, USA.

[64] Molaei, H., M. M. Kohansal, S. Karamifard, and S. S. Eslamian, 2014, climate change and its influence on the water level of Uremia Lake, The 4th International Conference on Environmental Challenges and Dendrochronologoy, Sari, Iran.

[65] Shafieyoun, E., Gheysari, M. and Eslamian, S. S., 2014, Identification of Micro-climates of Isfahan City and Its Effect on Average, Maximum and Minimum Air Temperature, Keynote Lecture, Proceeding of 3rd ScienceOne International Conference on Environmental Sciences, UAE.

[66] Eslamian, S. S., M. J. Amiri and W. Balderer, 2009, A Review on Thermal Spring in Iran, Groundwater, Thermal and Mineral Water in Areas of Arid Conditions: Consequences for the Current Situation of Climate Change and the Increasing Population of Egypt, IAH-CMTW Workshop, Cairo, Egypt.

[67] Eslamian, S. S., Khordadi, M. J., Baba Ahmadi, A. and J. Abedi-Koupai, 2009, Effects of Variations in Climate Parameters on Evapotranspiration in the Arid and Semiarid Regions, RCM2009, Lund University, Sweden.

[68] Eslamian, S. S. and H. Hasanzadeh, 2009, Climate Change Impact on Frequency Analysis of Wind Speed, IAMAS2009, 19-29 July, Montreal, Canada.

[69] Biabanaki M. and S. S. Eslamian, 2005, Monthly Flow Forecasting by Time Series Models in Ghezelozen River, Iran-Korea Climate Modeling Workshop, Mashhad, Iran.

[70] Soltani, S., Modarres R. and S. S. Eslamian, 2005, The Determination of Regional Rainfall Climates of Iran Based on Time Series Modeling, Iran-Korea Climate Modeling Workshop, Mashhad, Iran.

[71] Modarres, R. and S. S. Eslamian, 2003, Drought Frequency Analysis Using Markov Chain for Isfahan City, Third Regional Conference and First National Conference on Climate Change, University of Isfahan, Isfahan, Iran. 
[72] Nosrati, K., Mohseni Saravi, M., Eslamian S. S., Sharifi F. and M. Mahdavi, 2003, Identification of Homogeneous Regions in Hydrological Drought Using Multivariate Statistical Techniques in Arid and Semi-Arid Zones, Third Regional Conference and First National conference on Climate Change, University of Isfahan, Isfahan, Iran.

[73] Eslamian, S. S. and Y. Osroosh, 2002, The Impact of Dam Construction of Climate Parameters, Third Regional Conference and First National conference on Climate Change, University of Isfahan, Isfahan, Iran.

[74] Eslamian, S. S., Khajedin, S. J. and A. Amiri-Maleki, 2002, Role of dam construction in developing desert regions of arid zone climates, 8th International Conference on Understanding Future Dryland Environmental Changes from Past Dynamics, Yazd University, Iran.

[75] Zareian, M. J., Eslamian, S. S., and Safavi, H. R. 2016, Investigating the Effects of Sustainability of Climate Change on the Agriculture Water Consumption in the Zayandeh-Rud River Basin, Water and Soil Sci., Vol. 20, No. 75, 113-128.

[76] Gheisari, M., Eslamian, S. S., Shafieioun, E., Alikhasi, A., Ghaffari Sheshjavani, A., 2013, Microclimate Zoning of Isfahan City based on Surface Cover Type, Journal of Agricultural Meteorology Vol. 1, No. 2, 21-31.

[77] Nosrati, K., S. S. Eslamian and A. Shahbazi, 2004, Investigation of climate change effect on hydrologic drought, Journal of Agriculture, Vol. 6, No. 1, 49-56.

[78] Eslamian, S. S., 2009, Basin Ecology and Environment (BEE), International Journal of Ecological Economic \& Statistics, Ed., Special Issue Volume, CESER, Vol. 13, No. W09, 1-99.

[79] Gohari, A., Zareian, M. J., Eslamian, S., Nazari, R. 2017, Interbasin Transfers of Water: Zayandeh-Rud River Basin, Ch. 32 in Handbook of Drought and Water Scarcity, Vol. 2: Environmental Impacts and Analysis of Drought and Water Scarcity, Ed. by Eslamian S. and Eslamian F., Francis and Taylor, CRC Press, USA, 619-630.

[80] Goodarzi, E., Ziaei, L. and Eslamian, S., 2015, Recycled Water in Basin and Farm Scales, Urban Water Reuse Handbook, Ch. 65, Ed. By Eslamian, S., Taylor and Francis, CRC Group, 855-858.

[81] Kouhestani, S., Eslamian, S.S., Abedi-Koupai, J. and Besalatpour, A.A., 2016. Projection of climate change impacts on precipitation using soft-computing techniques: A case study in Zayandeh-rud Basin, Iran. Global and Planetary Change, No. 144, 158-170.

[82] Fathian, F., Dehghan, Z.., Eslamian, S., 2016, Evaluating the impact of changes in land cover and climate variability on streamflow trends (case study: eastern subbasins of Lake Urmia, Iran), J. Hydrology Science and Technology, Vol. 6, No. 1, 1-26.

[83] Yousefi, N., Safaee, A., Eslamian, S., 2015, The Optimum Design of Flood Control System Using Multivariate Decision Making Methods (Case Study: Kan River Catchment Basin, Iran), Journal of Flood Engineering, Vol. 6, No. 1, 63-82.

[84] Farshad F., Dehghan, Z., Eslamian, S., H. Bazrkar, 2015, Trends in hydrologic and climatic variables affected by four variations of Mann-Kendall approach in Urmia Lake basin, Iran, Hydrological Sciences Journal, DOI:10.1080/02626667.2014.932911.

[85] Bazrkar, M.H., Tavakoli-Nabavi, E., Zamani, N. and Eslamian, S., 2013, System dynamic approach to hydro-politics in Hirmand transboundary river basin from sustainability perspective, Int. J. Hydrology Science and Technology, Vol. 3, No. 4, 378-398.

[86] Zamani Nuri, A., Farzaneh, M. R., Fakhri, M., Dokoohaki, H., Eslamian, S. and Khordadi, M. J., 2013, Assessment of future climate classification on Urmia Lake basin under effect of climate change, Int. J. Hydrology Science and Technology, Vol. 3, No. 2, 128-140.

[87] Galoie, M., Zenz, G. and Eslamian, S., 2013, Determining the high flood risk regions using a rainfallrunoff modeling in a small basin in catchment area in Austria, Journal of Flood Engineering, Vol. 4, No. (1-2), 9-27.

[88] Galoie, M., Zenz, G. and Eslamian, S., 2013, Application of L-moments for IDF determination in an Austrian basin, Int. J. Hydrology Science and Technology, Vol. 3, No. 1, 30-48.

[89] Gohari, A., Eslamian, S., Abedi-Koupaei, J., Massah-Bavani, A., Wang, D., Madani, K., 2013, Climate change impacts on crop production in Iran's Zayandeh-Rud River Basin. Science of The Total Environment, Vol. 442, 405-419.

[90] Abdolhosseini, M., Eslamian, S., Mousavi, S. F., 2012, Effect of climate change on potential evapotranspiration: a case study on Gharehsoo sub-basin, Iran, Vol. 2 No. 4, 362-372.

[91] Alaghmand, S., Bin Abdullah, R., Abustan, I. and S. Eslamian, 2012, Comparison between capabilities of HEC-RAS and MIKE11 hydraulic models in river flood risk modeling (a case study of Sungai Kayu Ara River basin, Malaysia), International Journal of Environmental Science and Technology, Vol. 2, No. 3, 270-291. 
The Study on the Geo-Morphism Related Characteristics of Shiraz Geomorphic Basin, Fars Province, Iran

[92] Dhital, Y. P., Kayastha, R. B. and S. S. Eslamian, 2011, Precipitation and discharge pattern analysis: a case study of Bagmati River basin, Nepal, Journal of Flood Engineering, Vol. 2, No. 1, 49-60.

[93] Chavoshi Borujeni, S., Sulaiman, W. N. A. and S. S. Eslamian, 2010, Regional Flood Frequency Analysis Using L-Moments for North Karoon Basin Iran, Journal of Flood Engineering, Vol. 1, No. 1, 67-76.

[94] Eslamian, S. S. and M. J. Khordadi, 2009, Comparing Rainfall and Discharge Trends in Karkhe Basin, Iran, International Journal of Ecological Economics \& Statistics (IJEES), Vol. 15, No. F09, 114-122.

[95] Eslamian, S. S., 2009, Editorial: Frontiers in Ecology and Environment, International Journal of Ecological Economic \& Statistics, Special Issue on Basin Ecology and Environment (BEE), Vol. 13, No. W09, 1-6.

[96] Nosrati, K., Eslamian, S. S., Shahbazi, A., Malekian, A. and M. M. Saravi, 2009, Application of Daily Water Resources Assessment Model for Monitoring Water Resources Indices, International Journal of Ecological Economic \& Statistics, Special Issue on Basin Ecology and Environment (BEE), Vol. 13, No. W09, 88-99.

[97] Matouq, M., Amarneh, I. A., Kloub, N., Badran, O., Al-Duheisat, S. A. and S. S. Eslamian, 2009, Investigating the Effect of Combustion of Blending Jordanian Diesel Oil with Kerosene on Reducing the Environmental Impacts by Diesel Engine, International Journal of Ecological Economic \& Statistics, Special Issue on Basin Ecology and Environment (BEE), Vol. 13, No. W09, 79-87.

[98] Kohansal, M. M., Mohamadi, O., Eslamian, S. S. and M. Kohansal, 2014, Inter-basin Transfer and Saving Uremia Lake by Sustainable Development Approach, The 32nd National and the 1st International Geosciences Congress, Uremia, Iran.

[99] Eslamian, S. S. and S. A. Gohari, 2006, Investigation of Flooding Process in South-Esfahan Basin, International Congress of Islamic World Geographers, Esfahan University, Isfahan.

[100]Eslamian, S. S., Ghoudarzi, A. and R. Nazari, 2006, Investigation of the Changes of Permeability, Physical and Chemical Characteristics of Sediment Basins for Artificial Recharge in Bagh-E-Sorkh Region, Shahreza, Isfahan, 22nd Annual International Conference on Soils, Sediments and Water, University of Massachusetts at Amherst, USA.

[101]Saadati, S., Soltani-Koupai, S. and S. S. Eslamian, 2006, Frequency Analysis of Meteorological Drought Using Standard Precipitation Index (SPI) In Zayanderud Basin, First Regional Conference on Optimum Utilization of Water Resources in the Karun and Zayanderud Rivers Basins, Shahrekord University, 167.

[102]Keshavarzy, A., Erskine W. D. and S. S. Eslamian, 1995, River Management Vs. Urban Development in the Hawkesbury-Nepean River Basin, Australia, Regional Conference on Water Resources Management, Isfahan University of Technology, Isfahan, Iran, 629-637.

[103]Zareian, M. J., Eslamian, S. S., and Safavi, H. R. 2016, Investigating the Effects of Sustainability of Climate Change on the Agriculture Water Consumption in the Zayandeh-Rud River Basin, Water and Soil Sci., Vol. 20, No. 75, 113-128.

[104]Biabanaki M. and S. S. Eslamian, 2005, Cluster analysis for determination of the hydrologic homogeneity, assessment with discriminant analysis and Andrew curves in Karkheh basin, Scientific Journal of Agriculture, Vol. 6, No. 2. 13-26.

[105]Feyzi, H. and S. S. Eslamian, 2005, Comparing regional and at-site L-moments for estimation of maximum monthly rainfall in the Zayandehroud basin, Water and Wastewater Journal, Vol. 53, 1-13.

[106]Eslamian S. S., Zarei A. and A. Abrishamchi, 2004, Regional estimation of low flows for Mazandaran River basin, Journal of Science and Technology of Agriculture and Natural Resources, Vol. 8, No. 2., 27 38.

[107]Eslamian S. S., Zarei A. and A. Abrishamchi, 2003, Modified index flood method for estimating low flow in comparison with correlation method in Mazandaran basin, Journal of Agricultural Science and Technology, Vol. 17, No. 2., 153-160.

[108]Sattari, M. T., S. S. Eslamian and A. Abrishamchi, 2003, Optimization for distribution of water in Kalamarz multi-reservoir system, Mianeh basin, ESTEGHLAL, Journal of Engineering, Vol. 21, No. 2., 197-209.

[109]Sattari, M. T., A. Abrishamchi and S. S. Eslamian 2003, Simulation for distribution of water in Kalamarz multi-reservoir system, Mianeh basin, Journal of Agricultural Knowledge, Vol. 12, No. 3.

[110]Eslamian S., Shahmanosouri, M., A. Gohari, 2007, Study The Quality of Abterki River (Bazoft basin) for Hydroelectric Design, the 9th Seminar of Irrigation and Reduce Evaporation. University of Shahid Bahonar, Kerman, Iran.

[111] Saadati, S., Soltani-Koupai, S. and S. S. Eslamian, 2006, Frequency Analysis of Meteorological Drought Using Standard Precipitation Index (SPI) In Zayanderud Basin, First Regional Conference on Optimum Utilization of Water Resources in the Karun and Zayanderud Rivers Basins, Shahrekord University, 167. 
The Study on the Geo-Morphism Related Characteristics of Shiraz Geomorphic Basin, Fars Province, Iran

[112] Ostad-Ali-Askari, K., Shayannejad, M. 2015, Study of sensitivity of Autumnal wheat to under irrigation in Shahrekord, Shahrekord City, Iran. International Journal of Agriculture and Crop Sciences, 8 (4), 602-605.

[113]Shayannejad, M., Akbari, N., Ostad-Ali-Askari, K. 2015, Study of modifications of the river physical specifications on muskingum coefficients, through employment of genetic algorithm. International Journal of Development Research, 5(3), 3782-3785.

[114] Ostad-Ali-Askari, K., Shayannejad, M. 2015, The Reviews of Einstein's Equation of Logarithmic Distribution Platform and the Process of Changes in the Speed Range of the Karkheh River, Khuzestan province, Iran. International Journal of Development Research, 5(3), 3786-3790.

[115]Ostad-Ali-Askari, K., Shayannejad, M., Ghorbanizadee-Kharazi, H. 2015, Assessment of artificial neural network performance and exponential regression in prediction of effective rainfall, International Journal of Development Research, 5(3),3791-3794.

[116]Shayannejad, M. Akbari, N. and Ostad-Ali-Askari, K. 2015, Determination of the nonlinear Muskingum model coefficients using genetic algorithm and numerical solution of the continuity. Int. J. of Science: Basic and Applied Research, 21(1),1-14.

[117] Ostad-Ali-Askari, K., Shayannejad, M. 2015, The Study of Mixture Design for Foam Bitumen and the Polymeric and Oil Materials Function in Loose Soils Consolidation. Journal of Civil Engineering Research, 5(2), 39-44. DOI: 10.5923/j.jce.20150502.04

[118]Sayedipour, M., Ostad-Ali-Askari, K., Shayannejad, M. 2015, Recovery of Run off of the Sewage Refinery, a Factor for Balancing the Isfahan-Borkhar Plain Water Table in Drought Crisis Situation in Isfahan Province-Iran. American Journal of Environmental Engineering, 5(2): 43-46. DOI: 10.5923/j.ajee.20150502.02

[119] Ostad-Ali-Askari, K., Shayannejad, M. 2015, Developing an Optimal Design Model of Furrow Irrigation Based on the Minimum Cost and Maximum Irrigation Efficiency. International Bulletin of Water Resources \& Development, 3(2), 18-23.

[120]Ostad-Ali-Askari, K., Shayannejad, M. 2015, Presenting a Mathematical Model for Estimating the Deep Percolation Due to Irrigation. International Journal of Hydraulic Engineering, 4(1), 17-21. DOI: 10.5923/j.ijhe.20150401.03.

[121] Ostad-Ali-Askari, K., Shayannejad, M. 2015, Usage of rockfill dams in the HEC-RAS software for the purpose of controlling floods. American Journal of Fluid Dynamics, 5(1), 23-29. DOI: 10.5923/j.ajfd.20150501.03.

[122] Ostad-Ali- Askari, K., Shayannejad, M. 2015, The effect of heterogeneity due to inappropriate tillage on water advance and recession in furrow irrigation. Journal of Agricultural Science, 7(6), 127-136.

[123]Shayannejad, M., Ostad-Ali-Askari, K. 2015, Effects of magnetized municipal effluent on some chemical properties of soil in furrow irrigation. International Journal of Agriculture and Crop Sciences, 8(3), 482489.

[124]Ostad-Ali-Askari, K., Shayannejad, M. 2015, Optimal design of pressurized irrigation laterals installed on sloping land. International Journal of Agriculture and Crop Sciences, ISSN 2227-670X. 8(5), 792-797.

[125]Ostad-Ali-Askari K, Shayannejad M, Eslamian S, Navab-Pour B. 2016, Comparison of solution of SaintVenant equations by characteristics and finite difference methods for unsteady flow analyzing in open channel. International Journal of Hydrology Science and Technology, 6(3), 9-18.

[126] Ostad-Ali-Askari K, Shayannejad M, Eslamian S, et al. 2017, Deficit Irrigation: Optimization Models. Management of Drought and Water Scarcity. Handbook of Drought and Water Scarcity, Taylor \& Francis Publisher, USA. Vol. 3. 1th Edition, pp: 373-389.

[127]Eskandari S, Hoodaji M, Tahmourespour A, Abdollahi A, Mohammadian-Baghi T, Eslamian S, Ostad-AliAskari K. 2017, Bioremediation of Polycyclic Aromatic Hydrocarbons by Bacillus Licheniformis ATHE9 and Bacillus Mojavensis ATHE13 as Newly Strains Isolated from Oil-Contaminated Soil. Journal of Geography, Environment and Earth Science International, 11(2): 1-11.

[128] Shayannejad M, Ostad-Ali-Askari K, Eslamian S, et al. 2017, Development of a new method for determination of infiltration coefficients in furrow irrigation with natural non-uniformity of slope. Sustain. Water Resour. Manag., 3(2): 163-169.

[129]Shojaei N, Shafaei-Bejestan M, Eslamian S, Marani-Barzani M, P. Singh V, Kazemi M, Ostad-Ali-Askari K. 2017, Assessment of Drainage Slope on the Manning Coarseness Coefficient in Mountain Area. International Journal of Constructive Research in Civil Engineering (IJCRCE), 3(1): 33-40.

[130]Bahmanpour H, Awhadi S, Enjili J, Eslamian S, Ostad-Ali-Askari K. 2017, Optimizing Absorbent Bentonite and Evaluation of Contaminants Removal from Petrochemical Industries Wastewater. International Journal of Constructive Research in Civil Engineering (IJCRCE), 3(2): 34-42. 
The Study on the Geo-Morphism Related Characteristics of Shiraz Geomorphic Basin, Fars Province, Iran

[131]Shayannejad M, Eslamian S, Gandomkar A, Marani-Barzani M, Amoushahi-Khouzani M, Majidifar Z, Rajaei-Rizi F, Kazemi M, P. Singh V, Dehghan SH, Shirvani-Dastgerdi H.R, Norouzi H, Ostad-Ali-Askari K. 2017, A Proper Way to Install Trapezoidal Flumes for Measurements in Furrow Irrigation Systems. International Journal of Research Studies in Agricultural Sciences (IJRSAS), 3(7): 1-5.

[132]Dehghan Sh, Kamaneh S.A.A., Eslamian S, Gandomkar A, Marani-Barzani M, Amoushahi-Khouzani M, Singh V.P., Ostad-Ali-Askari K. 2017, Changes in Temperature and Precipitation with the Analysis of Geomorphic Basin Chaos in Shiraz, Iran. International Journal of Constructive Research in Civil Engineering (IJCRCE), 3(2): 50-57.

[133] Ostad-Ali-Askari K, Shayannejad M. 2016, FLOOD ROUTING IN RIVERS BY MUSKINGUM'S METHOD WITH NEW ADJUSTED COEFFICIENTS. International Water Technology Journal, IWTJ, 6(3): 189-194.

[134]Ostad-Ali-Askari K, Shayannejad M, Ghorbanizadeh-Kharazi H. 2017, Artificial Neural Network for Modeling Nitrate Pollution of Groundwater in Marginal Area of Zayandeh-rood River, Isfahan, Iran. KSCE Journal of Civil Engineering, 21(1):134-140. Korean Society of Civil Engineers. DOI 10.1007/s12205-016-0572-8.

[135] Shayannejad M, Ostad-Ali-Askari K, Ramesh A, Singh V.P., Eslamian S. 2017, Wastewater and Magnetized Wastewater Effects on Soil Erosion in Furrow Irrigation. International Journal of Research Studies in Agricultural Sciences (IJRSAS), 3(8): 1-14. http://dx.doi.org/10.20431/2454-6224.0308001.

[136]Shayannejad M, Soltani-Toudeshki A.R, Arab M.A, Eslamian S, Amoushahi-Khouzani M, MaraniBarzani M, Ostad-Ali-Askari K. 2017, A Simple Method for Land Grading Computations and its Comparison with Genetic Algorithm (GA) Method. International Journal of Research Studies in Agricultural Sciences (IJRSAS), 3(8): 26-38.

[137]Mohieyimen P, Eslamian S, Ostad-Ali-Askari K, Soltani M. 2017, Climate Variability: Integration of Renewable Energy into Present and Future Energy Systems in Designing Residential Buildings. International journal of Rural Development, Environment and Health Research(IJREH), 1(2): 18-30.

[138]Shayannejad M, Ostad-Ali-Askari K, Eslamian S, et al. 2017, Flow Hydraulic Investigation of the Wastewater on the Soil and Magnetic Field Effects in This Field. International Journal of Constructive Research in Civil Engineering (IJCRCE), 3(3): 1-15.

[139]Shayannejad M, Eslamian S, Singh V.P., Ostad-Ali-Askari K, et al. 2017, Evaluation of Groundwater Quality for Industrial Using GIS in Mountainous Region of Isfahan Province, Koh-Payeh, Isfahan, Iran. International Journal of Constructive Research in Civil Engineering (IJCRCE), 3(3): 24-37.

[140]Eslamian S, P. Singh V, Ostad-Ali-Askari K, R. Dalezios N, Yihdego Y, et al. 2017, Assessment of Aridity Using Geographical Information System in Zayandeh-Roud Basin, Isfahan, Iran. International Journal of Mining Science (IJMS), 3(2): 49-61.

[141]Askari Z, Samadi-Boroujeni H, Fattahi-Nafchi R, Yousefi N, Eslamian S, Ostad-Ali-Askari K, P. Singh V, R. Dalezios N. 2017, Prediction Comparison of Flow Resistance in Channels with Rounded and Angular Coarse Rough Beds. American Research Journal of Civil and Structural, 3(1): 1-15.

[142] Ghane M, Alvankar S.R., Eslamian S, Amoushahi-Khouzani M, Gandomkar A, Zamani E, Marani-Barzani M, Kazemi M, Soltani M, Dehghan SH, P. Singh V, Ostad-Ali-Askari K, Haeri-Hamedani M, ShirvaniDastgerdi H.R., Zalaki-Badil N. 2017, Sensitivity Analysis of Runoff Model by SWAT to Meteorological Parameters: A Case Study of Kasillian Watershed, Mazandaran, Iran. International Journal of Research Studies in Agricultural Sciences (IJRSAS), 3(10): 1-20.

[143] Shayannejad M, Abedi M.S., Eslamian S, Ostad-Ali Askari K, Gandomkar A, Cheng A, et al. 2017, The Contribution of Artificial Charging in Optimal Exploitation of Water Resources, Isfahan, Iran. InternationalJournal of Mining Science (IJMS), 3(3): 9-20.

[144]Eslamian S, Ostad-Ali Askari K, et al. 2017, Guidelines to Optimal Design of Furrow Irrigation Based on Plants, Soil and Furrow Specifications. International Journal of Constructive Research in Civil Engineering (IJCRCE), 3(4): 20-39.

Citation: Dr. Kaveh Ostad-Ali-Askari et al. (2017). The Study on the Geo-Morphism Related Characteristics of Shiraz Geomorphic Basin, Fars Province, Iran, International Journal of Mining Science (IJMS), 3(4), pp.10-23, DOI: http://dx.doi.org/ 10.20431/2454-9460.0304002.

Copyright: () 2017 Dr. Kaveh Ostad-Ali-Askari. This is an open-access article distributed under the terms of the Creative Commons Attribution License, which permits unrestricted use, distribution, and reproduction in any medium, provided the original author and source are credited 